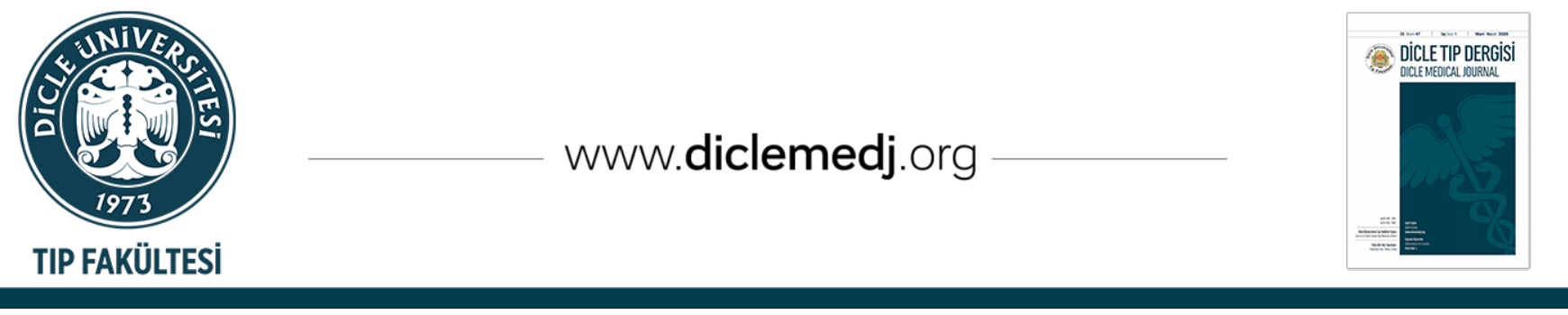

\title{
Diyarbakır İlinde Meydana Gelen İş Kazalarının Demografik Analizi, Mortalite ve Morbiditeyi Etkileyen Faktörler
}

\author{
Öner Avınca ${ }^{1}$ 1, Recep Dursun ${ }^{2}$, Mahmut Taş ${ }^{1}$, Mehmet Üstündăg ${ }^{i}{ }_{2}$, Murat Orak ${ }^{2}$, \\ Cahfer Güloğlu iD 2
}

1 S.B.Ü Gazi Yaşargil Eğitim Araştırma Hastanesi, Acil Tıp Abd. Diyarbakır, Türkiye

2 Dicle Üniversitesi Tıp Fakültesi Hastaneleri Acil Tıp Abd. Diyarbakır, Türkiye

Geliş: 02.06.2020; Revizyon: 07.08.2020; Kabul Tarihi: 07.08.2020

Öz

Amaç: İş: insanların yaşantısında onlara bir yer kazandıran önemli bir sosyal etmen olduğu gibi fiziksel, kimyasal, psikolojik, sosyal ve ekonomik pek çok nitelikleri ile de insan sağlığını etkilemektedir "1,2". Sanayi devrimi ile birlikte etkilenen çalışma hayatına hemen her alanda makineleşme girmiş ve bu durum kitlesel üretime geçişle paralel başka sorunları beraberinde getirmiştir. Bu sorunların en başında ise iş kazaları gelmektedir. Çalışanlar; kullandıkları makineler, çalışma ortamındaki zehirli maddeler, insan yapısına uygun olmayan çalışma organizasyonu gibi nedenlerle çeşitli mesleki tehlikelerle karşılaşmaktadır "3". Bu nedenle her yıl azımsanmayacak sayıda insan, çok rahatlıkla engellenebilecek iş kazalarından ve meslek hastalıklarından yaşamını kaybetmekte veya engelli hale gelmektedir "4".

Yöntemler: Bu çalışmada 1 Ocak 2013-31 Aralık 2015 tarihleri arasında meydana gelen iş kazaları geriye dönük olarak incelendi. Diyarbakır ili Dicle Üniversitesi Tıp Fakültesi Acil Tıp ve Travmatoloji Hastanesine başvuran hastaların arşivdeki dosyaları ile Sosyal Güvenlik Kurumu (SGK) kayıtlarına bakıldı. Çalışmaya dâhil edilen 406 olgunun yaş, cinsiyet gibi demografik özelliklerinin yanı sıra kazaların saat, gün, mevsim dağılımları gibi zamana bağlı başvuru şekilleri incelendi. Kazaların oluş yeri, acil servise başvuru şekli, kazanın oluş şekli, yaralanan organ, iş yeri özelliği, tedavi gördüğü ve/veya yattığı klinik ve sonuç parametreleri değerlendirildi.

Bulgular: Araştırmaya dâhil edilen işçilerin \%96,8'i (n=393) erkek, \%3,2'si (n=13) kadındı. Olguların mevsimlere göre dağılımı en sık \%30,8 ( $n=125)$ ile ilkbaharda görüldü. Hastalar en sık \%34,7 ( $n=141)$ oranı ile 12-16 saatleri arasında başvurdu. Olgular \%17,7 (n=72) ile en sık cumartesi günleri başvurdu. İş kazası nedeniyle acil servise başvuran hastaların kazanın olduğu yere göre dağılımları incelendiğinde; \%99'unun ( $\mathrm{n}=402)$ iş yerinde, \%0,5'inin ( $\mathrm{n}=2$ ) evde çalışırken kazaya maruz kaldığı tespit edilirken, \%0,5'inin ( $\mathrm{n}=2)$ ise nerede kazaya maruz kaldığı tespit edilemedi.

Sonuç: Çalışma yaşamının içindeki bir olgu olması nedeniyle iş kazaları, her şeyden önce üretim ilişkileri içindeki yeri, niteliği itibariyle değerlen dirilmelidir. İş yerleri, kâr amacıyla kurulan yerler olduklarından, iş kazalarına karşı alınacak her türlü önlem bir maliyet konusudur. İş kazalarının bir diğer önemli niteliği ise önlenebilir oluşudur.

Anahtar kelimeler: İș kazaları, iş, Diyarbakır, iş demografisi.

DOI: 10.5798/dicletip.800057

Correspondence / Yazışma Adresi: Öner Avınca, S.B.Ü Gazi Yaşargil Eğitim Araştırma Hastanesi, Acil Tıp Abd. Diyarbakır, Türkiye email:droneravinca@gmail.com 


\title{
Demographic Analysis of The Occupational Injuries In Diyarbakir, Factors Affecting Mortality And Morbidity
}

\begin{abstract}
Objective: Work is an important factor that gives social status in people's lives while effecting their health via physical, chemical, psychological, social and economic circumstances" 1,2 ". With the industrial revolution, mechanization has affected nearly all aspects of working life, and mass production is associated with a number of problems. One of the major problems is occupational injuries. Employees; faced with various occupational hazards due to reasons such as machines they use, poisonous substances in the working environment, work organization not suitable for human structure "3". Hence, a considerable number of people lose their lives or become disabled due to occupational injuries that can be prevented very easily "4".

Methods: In this study, occupatinal injuries that occurred between January 1, 2013 and December 31, 2015 were analyzed retrospectively. The archive files and Social Security Institution (SGK) records of patients who presented themselves to Dicle University Medical Faculty Emergency Medicine and Traumatology Hospital in Diyarbakır were examined. In addition to the demographic characteristics of the 406 cases included in the study, such as age, gender, time-based application such as seasonal distribution of injuries, day distribution and time distribution were examined. The place injuries occured, the way of applying to the emergency service, the type of injury, the injured organ, the type of occupation, the clinical and outcome parameters where he/she was treated or hospitalized were evaluated.

Results: The percentages of the employee genders, included in the study, are $96.8 \%(n=393)$ male and 3.2\% ( $n=13)$ female. The highest number of cases is observed in the spring season, with $30.8 \%(\mathrm{n}=125)$. The patients were presented to the Emergency Department most frequently between 12.00 and 16.00 , with $34.7 \%(\mathrm{n}=141)$. The Thursdays have the highest frequency of the cases presented, with $17.7 \%(\mathrm{n}=72)$. Considering the distribution of the location types that the occupational injury occurred, it is determined that $99 \%$ ( $n=402$ ) of the overall cases happened in the work environment, and $0.5 \%(n=2)$ of them happened while working at home. The remaining $0.5 \%(n=2)$ of the location of the occupational injury could not be identified.

Conclusion: Since it is a common phenomenon in working life, occupational injuries should first of all be evaluated in terms of their place in production relations. Since the workplaces are places established for profit, any precaution against work injuries is a cost issue. Another important feature of occupational injuries is that they can be prevented.
\end{abstract}

Keywords: Work, work injuries, Diyarbakır, work demographics.

\section{GíRiş}

İş, insanların yaşantısında onlara bir yer kazandıran önemli bir sosyal etmen olduğu gibi fiziksel, kimyasal, psikolojik, sosyal ve ekonomik pek çok nitelikleri ile de insan sağlı̆̆ını etkilemektedir ${ }^{1,2}$. Sanayi devrimi ile birlikte etkilenen çalışma hayatına hemen her alanda makineleşme girmiş ve bu durum kitlesel üretime geçişle paralel başka sorunları beraberinde getirmiştir. $\mathrm{Bu}$ sorunların en başında ise iş kazaları gelmektedir. Çalışanlar; kullandıkları makineler, çalışma ortamındaki zehirli maddeler, insan yapısına uygun olmayan çalışma organizasyonu gibi nedenlerle çeşitli mesleki tehlikelerle karşılaşmaktadır ${ }^{3}$. Bu nedenle her yıl azımsanmayacak sayıda insan, çok rahatlıkla engellenebilecek iş kazalarından ve meslek hastalıklarından yaşamını kaybetmekte veya engelli hale gelmektedir ${ }^{4}$. Çalışma ortamında gerekli güvenlik önlemlerinin alınmaması, hatalı davranışlar, kişisel yetersizlikler, teknik arızalar gibi nedenlerle ortaya çıkan iş kazaları; yaralanma, iş gücü kaybı, sakatlık, uzuv kayıpları ya da ölümle sonuçlanabilmenin yanı sıra, üretim sürecini de engellemektedir ${ }^{5,6}$. İş kazaları ile başvuran olgular acil servislerde sıkça görmeye alışık olduğumuz hasta gruplarındandır. Kişiye ve topluma yüklediği maddi ve manevi kayıplar nedeniyle kazaları önleme faaliyetleri üzerinde hassasiyetle durulması gereken acil problemlerden birisidir ${ }^{7}$. Ülkemizde acil servise başvuran iş kazaları olguları ile ilgili yapılan araştırmalar sınırlı sayıdadır. Bu çalışmada Diyarbakır ili Dicle Üniversitesi Tıp Fakültesi Acil ve Travmatoloji Hastanesine 1 Ocak 2013 ile 31 Aralık 2015 tarihleri arasında başvuran iş kazalarının araştırılması amaçlanmıştır. Kazazedelerin sosyodemografik özellikleri, kazanın oluş biçimi, kaza nedenleri, yaralanma bölgeleri ve tipleri, kazaların sektörel özellikleri ve son olarak neden olduğu sonuçlar araştırılmıştır. 


\section{YÖNTEMLER}

\section{Çalışma Alanı Ve Popülasyon}

Bu çalışmada 1 Ocak 2013-31 Aralık 2015 tarihleri arasında meydana gelen iş kazaları geriye dönük olarak incelendi. Diyarbakır ili Dicle Üniversitesi Tıp Fakültesi Acil Tıp ve Travmatoloji Hastanesine başvuran hastaların arşivdeki dosyaları ile Sosyal Güvenlik Kurumu (SGK) kayıtlarına bakıldı. Dicle Üniversitesi etik kurulu tarafından 26.02.2016 tarihinde 111 sayı numarası ile etik onay verildi.

\section{Veri Toplama ve Ölçümler}

Çalışmaya dâhil edilen 406 olgunun yaş, cinsiyet gibi demografik özelliklerinin yanı sıra kazaların saat, gün, mevsim dağılımları gibi zamana bağlı başvuru şekilleri incelendi. Kazaların oluş yeri, acil servise başvuru şekli, kazanın oluş şekli, yaralanan organ, iş yeri özelliği, tedavi gördüğü ve/veya yattığı klinik ve sonuç parametreleri değerlendirildi.

\section{Dışlama Kriterleri}

Çalışmaya 18 yaşından küçük olgular dâhil edilmedi. Dosyasına ulaşılamayan, eksik veri girişi olan ve SGK verilerine ulaşlamayan hastalar çalışmaya dâhil edilmedi.

\section{İstatistiksel Analiz}

Sonuçlar mean+SD olarak verildi. Univarite istatistiksel analizleri kategorik değişkenler için ki-kare testi ve sürekli değişkenler için student$\mathrm{t}$ testi kullanılarak yapıldı. $\mathrm{P}<0,05$ değeri istatistiksel olarak anlamlı kabul edildi.

\section{BULGULAR}

Araştırmaya dâhil edilen işçilerin \%96,8'i $(\mathrm{n}=393)$ erkek, \%3,2'si $\quad(\mathrm{n}=13) \quad$ kadındı.
Olguların mevsimlere göre dağılımı en sık $\% 30,8(n=125)$ ile ilkbaharda görüldü. Hastalar en sık \%34,7 ( $n=141)$ oranı ile 12-16 saatleri arasında başvurdu. Olgular \%17,7 (n=72) ile en sık cumartesi günleri başvurdu. İş kazası nedeniyle acil servise başvuran hastaların kazanın olduğu yere göre dağılımları incelendiğinde; \%99'unun ( $\mathrm{n}=402)$ iş yerinde, $\% 0,5^{\prime}$ inin $(\mathrm{n}=2)$ evde çalışırken kazaya maruz kaldığı tespit edilirken, \%0,5'inin $(n=2)$ ise nerede kazaya maruz kaldığı tespit edilemedi. İş kazası nedeni ile acil servise başvuran hastaların başvuru şekilleri incelendiğinde; olguların \%57,4'ü (n=233) direkt ayaktan acil servise başvururken, \%23,6'sı ( $\mathrm{n}=96)$ sevk ile \%19'u (n=77) 112 ambulans sistemi ile acil servise başvurdu.

İş kazası nedeniyle acil servise başvuran hastaların kazanın oluş şekline göre dağılımları değerlendirildi. Olguların \%57,8'i $\quad(n=235)$ vücudun zorlanmasına bağlı kırık-çıkıkincinme, \%15'i $(\mathrm{n}=61)$ yüksekten düşme, $\% 7,5^{\prime} \mathrm{u}(\mathrm{n}=30)$ elektrik akımına maruziyet, $\% 6,7$ 'si $(\mathrm{n}=27)$ vücuda yabancı cisim girmesi, $\% 5,2$ 'si $(n=21)$ trafik kazası, \%2,7'si (n=11) yanık, \%2'si (n=8) patlama nedeniyle ve $\% 3,1^{\prime} \mathrm{i}$ $(n=13)$ de diğer nedenlere bağlı olarak acil servise başvurdu.

İş kazası nedeniyle acil servise başvuran hastaların kazanın oluş şeklinin diğer değişkenlerle ilişkisi değerlendirildiğinde, kazanın oluş şekli ile iş yeri özelliği arasında anlamlı bulguya rastlandı (p:0,00). Kazanın oluş şekli ile yaş grupları, başvuru saati, kazanın olduğu alan ve sigortalı olma durumu arasında istatiksel olarak anlamlı bulguya rastlanmadı (tablo-1). 
Tablo I: İş Kazası Nedeniyle Acil Servise Başvuran Hastaların Kazanın Oluş Şeklinin Diğer Değişkenlerle İlişkisinin Karşılaştırılması

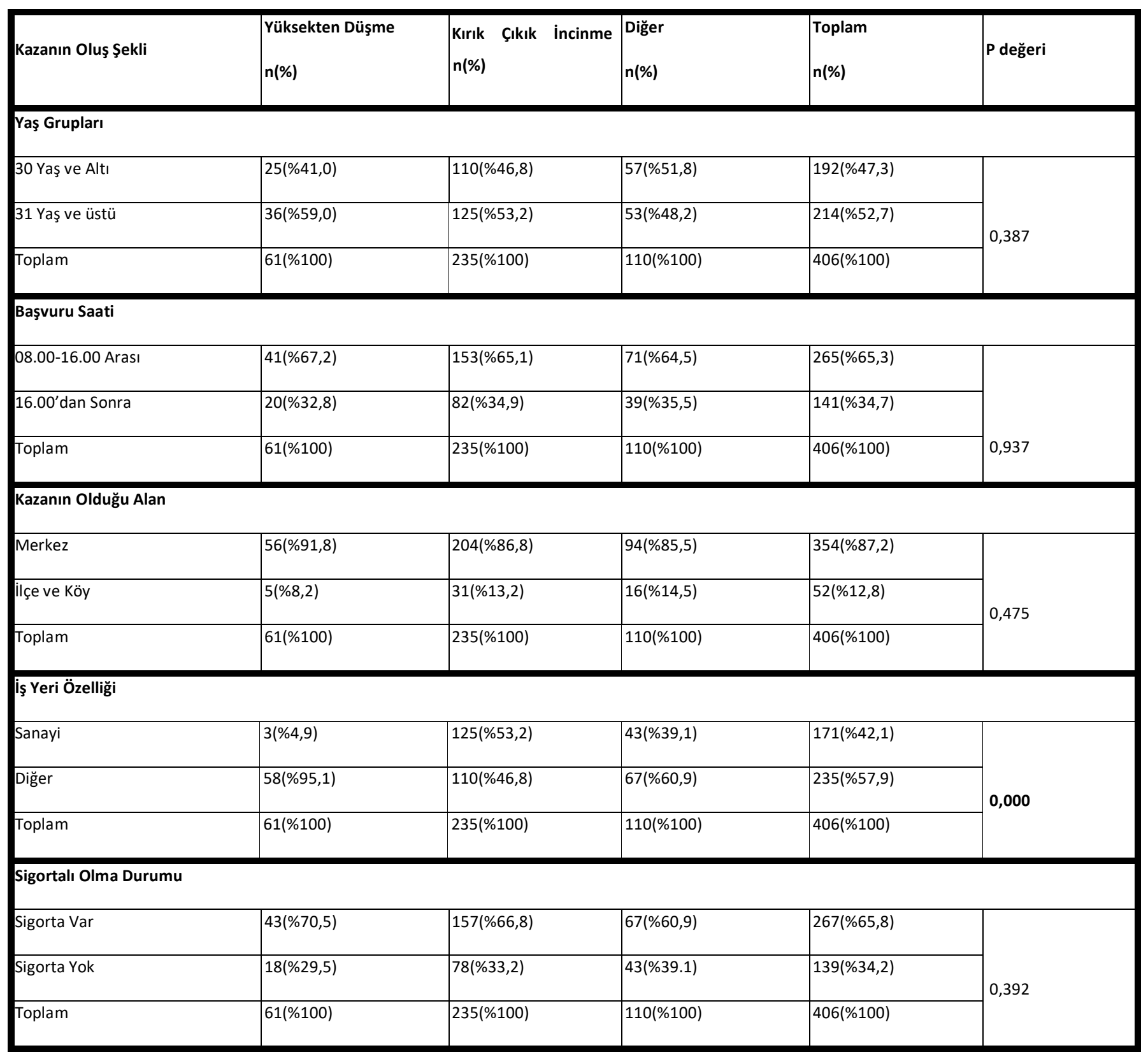

İş kazası nedeniyle acil servise başvuran hastaların yaralanma șekli ve yaralanan organlarına göre dağılımları incelendiğinde; olguların \%39,9'u (n=162) kesi, \%31,3'ü ( $n=127)$ ezilme, \%14,5'i (n=59) kırı, \%11,9'u $(\mathrm{n}=48)$ yanık, \%2,2'si $(\mathrm{n}=9)$ travma ve $\% 0,2$ 'si $(\mathrm{n}=1)$ de zehirlenme sonucu acil servise başvurdu. Olguların \%46,8'i $(n=190)$ üst ekstremite yaralanması ile başvururken, $\% 15,3$ 'ünde $(n=62)$ kafa, \%14,5'inde $(n=59)$ alt ekstremite, \%7,1'inde (n=29) göz, \%6,4'ünde $(n=26)$ toraks, \%4,4'ünde $(n=18)$ vertebra, $\% 3$ 'ünde $(n=12)$ batın, $\% 2,5^{\prime}$ inde $(n=10)$ pelvis yaralanması görüldü. İş kazaları sonucu yaralanma şekli ile iş yeri özelliği arasında anlamlı istatiksel değere rastlandı (p:0,004). Yaş grupları, başvuru saati, başvuru şekli ve sigortalı olma durumları ile yaralanma şekli arasında anlamlı bulguya rastlanmadı (tablo-2). 
Tablo II: İş Kazası Nedeniyle Acil Servise Başvuran Hastaların Yaralanma Şekillerinin Diğer Değişkenlerle İlişkisinin Karşılaștırılması

\begin{tabular}{|c|c|c|c|c|}
\hline Yaralanma Şekli & $\begin{array}{l}\text { Yanık- } \\
\text { Zehirlenme } \\
\text { n(\%) }\end{array}$ & $\begin{array}{l}\text { Kırık-Kesik- } \\
\text { Ezilme-Travma } \\
\text { n(\%) }\end{array}$ & $\begin{array}{l}\text { Toplam } \\
\text { n(\%) }\end{array}$ & P değeri \\
\hline \multicolumn{5}{|l|}{ Yaş Grupları } \\
\hline 30 yaş ve altı & $25(\% 51,0)$ & $167(\% 46,8)$ & $192(\% 47,3)$ & \multirow{3}{*}{0,577} \\
\hline 31 yaş ve üstü & $24(\% 49,0)$ & $190(\% 53,2)$ & $214(\% 52,7)$ & \\
\hline Toplam & $49(\% 100)$ & $357(\% 100)$ & $406(\% 100)$ & \\
\hline \multicolumn{5}{|l|}{ Başvuru Saati } \\
\hline $\begin{array}{l}08.00-16.00 \\
\text { arası }\end{array}$ & $34(\% 69,4)$ & $231(\% 64,7)$ & $265(\% 65,3)$ & \multirow{3}{*}{0,519} \\
\hline 16.00 'dan sonra & $15(\% 30,6)$ & $126(\% 35,3)$ & $141(\% 34,7)$ & \\
\hline Toplam & $49(\% 100)$ & $357(\% 100)$ & $406(\% 100)$ & \\
\hline \multicolumn{5}{|l|}{ Başvuru Şekli } \\
\hline Direkt Başvuru & $27(\% 55,1)$ & $206(\% 57,7)$ & $233(\% 57,4)$ & \multirow{3}{*}{0,730} \\
\hline Sevk-Ambulans & $22(\% 44,9)$ & $151(\% 42,3)$ & $173(\% 42,6)$ & \\
\hline Toplam & $49(\% 100)$ & $357(\% 100)$ & $406(\% 100)$ & \\
\hline \multicolumn{5}{|c|}{ Sigortalı Olma Durumu } \\
\hline Sigorta Var & $30(\% 61,2)$ & $237(\% 66,4)$ & $267(\% 65,8)$ & \multirow{3}{*}{0,475} \\
\hline Sigorta Yok & $19(\% 38,8)$ & $120(\% 33,6)$ & $139(\% 34,2)$ & \\
\hline Toplam & $49(\% 100)$ & $357(\% 100)$ & $406(\% 100)$ & \\
\hline \multicolumn{5}{|l|}{ İş Yeri Özelliği } \\
\hline Sanayi & $30(\% 61,2)$ & $141(\% 39,5)$ & $171(\% 42,1)$ & \multirow{3}{*}{0,004} \\
\hline Diğer & $19(\% 38,8)$ & $216(\% 60,5)$ & $235(\% 57,9)$ & \\
\hline Toplam & $49(\% 100)$ & $357(\% 100)$ & $406(\% 100)$ & \\
\hline
\end{tabular}

İş kazası nedeniyle acil servise başvuran hastaların yaralanan organlarının diğer değişkenlerle ilişkisinin karşılaştırılması sonucu: yaralanan organ ile başvuru şekli (p:0,001), kazanın oluş şekli (p:0,000), sigortalı olma durumu (p:0,002) ve iş yeri özelliği arsında (p:0,002) anlamlı bulguya rastlandı. Yaș grupları, başvuru saati ve yaralanma şekli arasında anlamlı bulguya rastlanmadı.

İş kazası nedeniyle acil servise başvuran hastaların iş yeri özelliklerine göre dağılımları değerlendirildi. Olguların \%42,1'i (n=171) sanayi sitesinde, \%19,5'i (n=79) inşaatta, \%8,1'i $(n=33)$ çeşitli fabrikalarda, \%2'si ( $n=8)$ nakliyat sektöründe, \%1,7'si (n=7) kereste sanayide, $\% 0,7$ 'si $(n=3)$ oto tamiri sanayide, \%25,9'u (n=105) da diğer (küçük çaplı esnaf, dükkân, kasap, market vb) iş yerlerinde gerçekleşen kazalar sonucu acil servise başvurdu.

İş kazası nedeniyle acil servise başvuran hastaların tedavi gördüğ̈u, yattığı servis ve tedavi sonuçlarına göre dağılımları incelendi. Olguların \%46,1'i (n=187) acil serviste, \%26,1'i $(n=106)$ plastik ve rekonstrüktif cerrahi kliniğinde, \%12,8'i (n=52) ortopedi kliniğinde, $\% 6,2$ 'si $(n=25)$ göz kliniğinde, \%4,7'si $(n=19)$ beyin cerrahi kliniğinde, \%1,5’i $(n=6)$ genel cerrahi kliniğinde, \%1,2'si $(n=5)$ gögüs cerrahi kliniğinde, \%0,7'si $(n=3)$ üroloji kliniğinde, $\% 0,5$ 'i $(n=2)$ anestezi ve reanimasyon kliniğinde, \%0,2'si $(n=1)$ kalp damar cerrahi kliniğinde tedavi gördü. Acil servise başvuran 406 olgunun \%84,6'sı (n=343) şifa ile taburcu olurken, \%8,1'i $(n=33)$ ampütasyon (el parmakları, ayak parmakları), \%3,4'ü $(n=14)$ tedaviyi ret, \%1,7 'si (n=7) başka bir merkeze sevk, \%1'i $(n=4)$ izinsiz kliniği terk ile sonuçlandı. Son olarak da \%1,2'si $(n=5)$ ex oldu. İş kazası sonucu acil servise başvuran hastaların tedavi gördüğü, yattığı servis ve tedavi sonuçları ile diğer verilerin istatiksel analizleri değerlendirildi. Hastaların tedavi sonuçları ile işyeri özelliği arasında (p:0,019) ve tedavi sonuçları ile hastanın yattığı klinik arasında (p:0,019) istatiksel olarak anlaml bulguya rastlandı. Tedavi sonuçları ile yaş grupları, başvuru saati, kazanın olduğu alan, kazanın oluş şekli, sigortalı olma durumu, yaralanan organ ve yaralanma şekli arasında anlamlı istatiksel bulguya rastlanmadı (tablo-3). 
Tablo III: İş Kazası Nedeniyle Acil Servise Başvuran Hastaların Taburcu Olma Biçimlerinin Diğer Değișkenlerle İlişkisinin Karşılaștırılması

\begin{tabular}{|c|c|c|c|c|}
\hline Sonuç & Şifa ile taburcu n(\%) & $\begin{array}{l}\text { Ölüm, ampütasyon, tedavi reddi, } \\
\text { sevk, izinsiz terk, diğer n(\%) }\end{array}$ & $\begin{array}{l}\text { Toplam } \\
\text { n(\%) }\end{array}$ & P değeri \\
\hline \multicolumn{5}{|l|}{ Yaş Grupları } \\
\hline 30 yaș ve altı & $165(\% 48,1)$ & $27(\% 42,9)$ & $192(\% 47,3)$ & \multirow{3}{*}{0,443} \\
\hline 31 yaș ve üstü & $178(\% 51,9)$ & $36(\% 57,1)$ & $214(\% 52,7)$ & \\
\hline Toplam & $343(\% 100)$ & $63(\% 100)$ & $406(\% 100)$ & \\
\hline \multicolumn{5}{|l|}{ Başvuru Saati } \\
\hline 08.00-16.00 arası & $228(\% 66,5)$ & $37(\% 58,7)$ & $265(\% 65,3)$ & \multirow{3}{*}{0,235} \\
\hline 16.00'dan sonra & $115(\% 33,5)$ & $26(\% 41,3)$ & $141(\% 34,7)$ & \\
\hline Toplam & $343(\% 100)$ & $63(\% 100)$ & $406(\% 100)$ & \\
\hline \multicolumn{5}{|c|}{ Kazanın Olduğu Alan } \\
\hline Merkez & $302(\% 88)$ & $52(\% 82,5)$ & $354(\% 87,2)$ & \multirow{3}{*}{0,229} \\
\hline İlçe ve Köy & $41(\% 12)$ & $11(\% 17,5)$ & $52(\% 12,8)$ & \\
\hline Toplam & $343(\% 100)$ & $63(\% 100)$ & $406(\% 100)$ & \\
\hline \multicolumn{5}{|l|}{ Kazanın Oluş Şekli } \\
\hline Yüksekten düşme & $54(\% 15,7)$ & $7(\% 11,1)$ & $61(\% 15,0)$ & \multirow{4}{*}{0,422} \\
\hline Kırık Çılkık İncinme & $194(\% 56,6)$ & $41(\% 65,1)$ & $235(\% 57,9)$ & \\
\hline Diğer & $95(\% 27,7)$ & $15(\% 23,8)$ & $110(\% 27,1)$ & \\
\hline Toplam & $343(\% 100)$ & $63(\% 100)$ & $406(\% 100)$ & \\
\hline \multicolumn{5}{|c|}{ Sigortalı Olma Durumu } \\
\hline Sigorta Var & $223(\% 65,0)$ & $44(\% 69,8)$ & $267(\% 65,8)$ & \multirow{3}{*}{0,458} \\
\hline Sigorta Yok & $120(\% 35,0)$ & $19(\% 30,2)$ & $139(\% 34,2)$ & \\
\hline Toplam & $343(\% 100)$ & $63(\% 100)$ & $406(\% 100)$ & \\
\hline \multicolumn{5}{|l|}{ Yaralanan Organ } \\
\hline Baş boyun-Göz & $83(\% 24,2)$ & $8(\% 12,7)$ & $91(\% 22,4)$ & \multirow{4}{*}{0,083} \\
\hline Üst/Alt Ekstremite & $203(\% 59,2)$ & $46(\% 73,0)$ & $249(\% 61,3)$ & \\
\hline Diğer & $57(\% 16,6)$ & $9(\% 14,3)$ & $66(\% 16,3)$ & \\
\hline Toplam & $343(\% 100)$ & $63(\% 100)$ & $406(\% 100)$ & \\
\hline \multicolumn{5}{|l|}{ Yaralanma Şekli } \\
\hline Yanık-zehirlenme & $42(\% 12,2)$ & $7(\% 11,1)$ & $49(\% 12,1)$ & \multirow{3}{*}{0,800} \\
\hline $\begin{array}{l}\text { Kırık-Kesik-Ezilme- } \\
\text { Travma }\end{array}$ & $301(\% 87,8)$ & $56(\% 88,9)$ & $357(\% 87,9)$ & \\
\hline Toplam & $343(\% 100)$ & $63(\% 100)$ & $406(\% 100)$ & \\
\hline \multicolumn{5}{|l|}{ İş Yeri Özelliği } \\
\hline Sanayi & $136(\% 39,7)$ & $35(\% 55,6)$ & $171(\% 42,1)$ & \multirow{3}{*}{0,019} \\
\hline Diğer & $207(\% 60,3)$ & $28(\% 44,4)$ & $235(\% 57,9)$ & \\
\hline Toplam & $343(\% 100)$ & $63(\% 100)$ & $406(\% 100)$ & \\
\hline \multicolumn{5}{|c|}{ Hastanın Yattığı Servis } \\
\hline Acil Servis & $174(\% 50,7)$ & $13(\% 20,6)$ & $187(\% 46,1)$ & \multirow{4}{*}{0,000} \\
\hline Plastik Cerrahi & $70(\% 20,4)$ & $36(\% 57,1)$ & $106(\% 26,1)$ & \\
\hline Diğer & $99(\% 28,9)$ & $14(\% 22,2)$ & $113(\% 27,8)$ & \\
\hline Toplam & $343(\% 100)$ & $63(\% 100)$ & $406(\% 100)$ & \\
\hline
\end{tabular}




\section{TARTIŞMA}

Uluslararası Çalıșma Örgütü (ILO) verilerine göre dünya sanayi üretiminde her yıl ortalama 50 milyon iş kazası olmakta; bu kazalar nedeniyle yaklaşık 100,000 kişi ölmekte, 1,5 milyon kişi de sürekli iş göremezlik nedeniyle üretim dışında kalmakta. Gelişmiş sanayi ülkelerinde her yıl çalışan on kişiden biri iş kazası geçirmekte, bazı iş kollarında bu oran üçte birler oranına yükselmektedir. Yani bu iş kollarında çalışan her üç kişiden biri iş kazasıyla karşı karşıya kalmaktadır8.

Çalışmamız 1 Ocak 2013 ile 31 Aralık 2015 tarihleri arasında acil servise başvuran olgulardan oluşmaktadır. SGK 2014 verilerine göre başvuran 221366 iş kazasının 28174 kadarı kadın çalışanlardan oluşmaktadır. Bu sayılara göre 2014 yılında meydana gelen iş kazalarının yaklaşık \%12,7'si (n=27) kadın çalışanlardan oluşmaktadır ${ }^{9}$. Benzer çalışmalar incelendiğinde; Adana Numune Eğitim Araştırma Hastanesinde \%3,4510, İstanbul ilinde yapılan genel bir çalışmada kadın kazazedeler $\% 0,2$ düzeyinde bulundu ${ }^{11}$. Yine Edirne merkezli bir giyim fabrikasında yapılan bir çalışmada kazazedelerin \%75,2'si kadın olarak tespit edildi ${ }^{12}$. Bizim çalışmamızda başvuran 406 hastanın 13 tanesi kadın olarak görüldü: bu tüm olguların \%3,2'sini içermektedir. Bu veriler ışığında görülmüştür ki iş hayatının farklı kollarında meydana gelen kazalarda cinsiyet farklılı̆̆ görülmektedir. Daha fazla bedensel güç gerektiren iş kollarında çalışanların çoğunu erkekler oluşturduğu için meydana gelen kazalarda en fazla erkek popülâsyonu etkilenmektedir. Aynı zamanda ev işlerinde gerçekleşen kazalarda erkeklerin sayısı azımsanmayacak kadar çoktur bu da yine bölgesel farklılıklar göstermektedir.

Ankara elektrik dağıtım işlerinde çalışanlar arasında yapılan bir çalıșmada yaş ortalaması 33,12 bulunurken kazalar en fazla 20-30 yaş aralığında \%29,5 (n=29) olarak tespit edildi13. 1984 yılında yapılan bir kamu sektöründe çalışanlara yönelik derlemede 3462 olgudan 1061'i 31-35 yaş aralığında olduğu görüldü14. Sayhan ve ark. yaptığı bir çalışmada hastaların ortalama yaşı 36.03 \pm 11.77 ydi $^{23}$. Çalışmamızdaki olguların yaş ortalaması $32,8 \pm 9,6$ olarak tespit edildi. En fazla sayıyı 1825 yaş aralığındaki kazazedeler \%25,6 $(n=104)$ ile oluşturmakta idi. Benzer yapılmış olan birçok çalışmada yaş ortalamalarındaki farklılığın bölgelere göre farlılıklar gösterdiği gözlemlenmiştir.

Sosyal Güvenlik Kurumunun (SGK) 2014 verilerinde iş kazalarının aylara göre dağılımında en sık ilkbahar, yaz mevsimlerinde kazalar görülmektedir (Haziran:20167, Temmuz:18888, Ağustos:20828, Eylül:20170)9. Atatürk Barajı Hidroelektrik Santrali'nin yapımında meydana gelen iş kazalarına yönelik bir çalışmada kasım ayında \%18,0 (n=34), Aralık ayında \%16,9 (n=32), Temmuz ayında $\% 13,2(n=25)$ olgu tespit edilmiștir ${ }^{15}$. Türkiye Taş Kömürü Kurumu Kozlu Müessesesi 2004 yılında yapılan iş kazaları değerlendirmesinde en sık \%12,0 $(n=54)$ ile ağustos ayında iş kazaları görülürdü16. Çalışmamızdaki olgularda SGK verilerine paralellik göstermektedir. İş kazalarının mevsimsel dağılımı ilkbahar \%30,8 $(n=125)$, yaz \%23,4 ( $n=95)$, kış \%24,1 ( $n=98)$ ve sonbahar \%21,7 $(\mathrm{n}=88)$ oranında görüldü. Mevcut çalışma verilerinin ışığında ve çalışmamızda elde ettiğimiz verilere göre iş kazalarının kümeleştiği belirgin bir ay ya da mevsim yoktur. Kazaların aylara ve mevsimlere dağılımı yakın değerlerdedir. İş kazasına maruz kalanlar genellikle kapalı alanlarda çalışmaktadırlar. Bundan dolayı iş kazaları mevsimlerden çok fazla etkilenmemektedir. Mevsimsel işçilerin uğradığı kazalar hakkında yeterli veri olmadığından kazaların mevsimsel dağılımı üzerine etkisi net olarak yansitılamamaktadır.

Çalışmamızda iş kazası olgularının çoğunluğu 08.00-16.00 saatleri arasında başvurdu. Bu da iş kazalarının genel anlamda mesai saatleri 
içerisinde meydana geldiğini gösterdi. Ankara Elektrik Dağıtım Şirketinde çalışan iş̧̧ilere yönelik yapılan bir çalışmada iş kazalarının en sık meydana geliş saatleri 14.00-15.00 arasındayd $1^{13}$. Atatürk Barajı Hidroelektrik Santrali yapımında çalışan işçilerde meydana gelen iş kazalarına yönelik yapılan çalışmada yine en sık mesai saatlerinde kazalar meydana geldi ${ }^{15}$. Yapılan çalışmalar bizim çalışmamıza genel anlamda paralellik göstermektedir. Erken saatte meydana gelen kazalar işçilerin işe başlarken ki konsantrasyon eksikliğinden kaynaklı olabilir. Mesai bitimine doğru oluşan iş kazaları ise çalışanların işi erken bitirme arzularından dolayı gerçekleşiyor olabilir. Bizim çalışmamızda da özellikle sabah olmak üzere mesai saatlerinde kaza oranı daha yüksek bulunmuştur.

İş kazalarının başvuru günlerine baktığımızda bizim çalışmamızda cumartesi günü başvuran olgu sayısı nispeten daha fazla görülse de haftanın ilk günlerinde daha fazla olgu görülmektedir. Yapılan çalışmaların çoğunda haftanın ilk günlerinde kaza oranının daha yoğun olduğu görüldü. Bunun da çalışanların hafta başında işe tam odaklanmadan başlamaları, ilk günlerde iş yoğunluğunun fazlalığı gibi durumlara bağlı gerçekleşmiş olabileceği düşünüldü.

Çalışmamızda en sık başvuru şekli direkt (özel araç veya ayaktan) \%57,4 (n=233) olarak saptandı. Yapılan benzer bir çalışmada Pamukkale Üniversitesi'nde olguların \%68,6'sı $(n=362)$ direkt başvuru ile acil servise gelmiştir ${ }^{17}$. Bu da bizim çalıșmamızla paralellik göstermektedir. Kazazedelerin acil servise başvuru şekilleri arasında direkt başvuruların fazla olmasının nedeni; kaza anında kazazedenin yakınında bulunan kişilerin bilinçsizce kazazedeyi hastaneye yetiştirme arzusundan kaynaklanıyor olabilir. Acil servise başvuru şekli ile ilgili çok fazla çalışma bulunmamasına rağmen bizim çalışmamız göstermiştir ki; iş kazalarında başvuruların çoğu ayaktan ya da kazazedenin yakınındaki kişiler tarafından acil servise getirilmesi ile olmaktadır.

Ege Üniversitesi Hastanesi'nde çalışan ev idaresi personellerinin iş kazası geçirme durumları ile ilgili yapılan bir çalışmada kazanın oluş şekli olarak en sık iğne batması $\% 21,8$, kesikler $\% 18,2$, açı yaralanmalar $\% 16,4$ ve slyrıklar $\% 16,4$ oranında görüldü18. İstanbul ilinde bir şantiyede yaplan çalışmada kazaların oluş şekilleri cisim çarpması \%49,0 ( $\mathrm{n}=100)$, slkışma \%12,3 ( $\mathrm{n}=25)$, düşme $\% 11,3 \quad(\mathrm{n}=23)$ olarak tespit edildi ${ }^{19}$. Salt ve ark.yaptığ 1 çalışmada en sık yaralanma mekanizması aynı seviyeden ya da yüksekten düşme $\% 56.7$ ( $n=74)$ olarak görüldü ${ }^{24}$. Yapılan tüm çalışmalar göstermiştir ki işin şekli, çalışma koşulları, çalışılan alan, çalışılan makineler, çalışılan saatler iş yerinde oluşan kazaların oluş şekillerini belirlemektedir. Bizim çalışmamızda kazazedelerin çoğunun vücudun zorlanmasına bağlı kazalar sonucu acil servise başvurduğu gözlendi. İş̧ şeklinin bölgesel, şehirsel farklılıklar göstermesi çalışmamızı da etkiledi ve nitekim daha fazla makinelerle temas sonrası oluşan yaralanmalar görüldü.

Çalışmamızda yaralanma şekillerini en sık \%39,9 (n=162) ile kesikler olușturmaktadır. Ezilme ile başvurular \%31,3 ( $\mathrm{n}=127)$, kırık ile $\% 14,5 \quad(n=59)$ oranında belirlenmiş olup sıralamada ilk üçtedirler. Yaralanma șekli ile ilgili yapılan diğer çalışmalar: Pamukkale Üniversitesi'nde en sık kesici-delici alet, sıyrık, ampütasyon yaralanmaları \%43,4 (n=229) görüldü17. Ayrıca SGK 2014 verilerine göre yaralar ve yüzeysel yaralanmalar 101158, kırıklar 17202, çıkıklar ve burkulmalar 31571 olguda görülüp ilk üç sırayı oluşturdu' ${ }^{9}$. Bu da çalışmamızın hem diğer çalışmalarla hem de SGK verileri ile paralellik gösterdiği anlamına gelmektedir. Çalışılan iş kolunun yaralanma şekli üzerinde etkili olduğu hem bizim hem de diğer çalışmalarda görüldü. Çalışmamız diğer çalışmalarla paralellik göstermektedir. $\mathrm{Bu}$ da 
gösteriyor ki çalışılan yerdeki makinelerin kurulumu, çalışma şekilleri, özellikleri yaralanma şekilleri üzerinde belirleyici olmaktadır.

Kalemoğlu ve ark. bir araştırmasında, üst ekstremitenin delici, kesici, ampute yaralanmaları \%43,0 ile ilk sırayı almıștır ${ }^{20}$. Kıran ve ark. (2006) bir çalışmasında \%41'lik yaralanma oranı ile üst ekstremitenin önlerde yer aldığı ve bunu alt ekstremite, baş-boyun ve gövde yaralanmalarının takip ettiğini bildirildi $^{21}$. SGK 2014 verilerine göre de yaralanma yerleri üst ekstremite 85566, alt ekstremite 42223 ve kafa yaralanmaları 26349 olarak açıklandı9. Bizim çalışmamızda da benzer çalışmalarla paralellik göstererek en sık üst ekstremite yaralanmaları \%46,8 $(n=190)$ oranında görüldü. Yapılan çalışmalar göstermiştir ki iş kazalarında en sık yaralanan organlar ekstremitelerdir. En slk ekstremitelerin yaralanmasının nedeni yapılan işlerin daha çok el becerisi ve el hâkimiyeti isteyen işler olmasıdır. Ev kazaları ile ilgili yapılan çalışmalarda da ekstremite yaralanmaları sık görülmüştür.

Yaptığımız istatiksel çalışmada yaralanan organ ile hastaneye başvuru şekli arasında yüksek düzeyde istatiksel anlamlılık tespit edildi. $\mathrm{Bu}$ durum yaralanan organın farklılığına bağlı olarak kazazedenin yakınında bulunan kişilerin hastayı kendi imkânları ile taşımak yerine 112 ambulansının gelmesini beklemelerinden kaynaklanıyor olabilir. Kazanın oluş şekli ile yaralanan organ arasında da yüksek istatiksel anlamlılık tespit edildi. Bu sonuç kazanın oluş şekline bağlı yaralanan organ hakkında bize bilgi vermektedir. Vücudun zorlanması ile oluşan kırık, çıkık, incinme gibi durumlarda daha sıklıkla yaralanan organlar ekstremite iken, yüksekten düşme gibi durumlarda yaralanan organ vertebra, batın veya baş-boyun olabilmektedir. Yaralanan organ ile sigortalı olma durumu arasında da yüksek istatiksel anlamlılık tespit edildi. Sigortalı işçi çalıştıran işverenlerin güvenlik önlemlerine daha fazla önem vermelerine bağlı yaralanan organ farklılık gösteriyor olabilir. Aynı şekilde yaralanan organ ile iş yeri özelliği arasında da yüksek istatiksel anlamlılık tespit edildi. İş yerinin fiziki şartları, makinelerin dizilimi ve ilgili olduğu iş yaralanan organ üzerinde etkili olabilir.

Çalışmamızda en sık iş yeri \%42,1 (n=171) oranında sanayi olarak tespit edildi. Çalışmamız göstermiştir ki Diyarbakır ilinde sanayi sitelerinde iş kazaları daha fazla görülmektedir. Sanayi sitelerinde daha fazla kaza görülmesindeki nedenler çalışan sayısının fazlalığı ve şehrin gelişmişliğine bağlı sanayi alanının büyük olması kaynaklı olabilir. Genel anlamda çalışmamızda iş̧̧i sayısının fazla olduğu alanlarda kaza sayısı da fazla görüldü.

Ankara ili elektrik dağıtım işlerinde çalışan işçilere yönelik yapılan çalışmada en sık önemsiz küçük yaralar \%29,0 (n=18) oranında tespit edildi ve tedavileri ayaktan yapıld $1^{13}$. Çukurova Üniversitesi Tıp Fakültesi'nde yapılan çalışmada hastaların \%41'inin acil serviste tanı ve tedavisi yapıldı ${ }^{22}$. Bizim çalışmamızda benzer çalışmalara paralellik göstermektedir. Acil serviste tedavi edilen hastalar \%46,1 $(n=187)$ ile ilk sırada yer almaktadır. Verilere göre acil servise başvuran kazaların çoğunun ayaktan tedavi edilebilecek olgular olduğu söylenebilir. Ayrıca acil servislerdeki eğitimin düzeyi, malzeme ve personel yeterliliği müdahale yeteneğini arttırmış olabilir.

Çalışmamızda acil servise başvuran hastaların takip ve tedavileri sonucu son durumlarına bakıldığında \%84,5 ( $\mathrm{n}=343)$ şifa ile taburculuk görüldü. Tüm olgular içinde $\% 1,2(n=5)$ exitus oldu. Çalışmamızdaki veriler benzer çalışmalara paralellik göstermektedir.

\section{SONUÇ}

Çalışma yaşamının içindeki bir olgu olması nedeniyle iş kazaları, her şeyden önce üretim ilişkileri içindeki yeri, niteliği itibariyle 
değerlendirilmelidir. İş yerleri, kâr amacıyla kurulan yerler olduklarından, iş kazalarına karşı alınacak her türlü önlem bir maliyet konusudur. İş kazalarının bir diğer önemli niteliği ise önlenebilir oluşudur. Çalışma ortamı, iş akışının niteliği, çalışma işbirlikleri, mesleki eğitim, çalışma ve dinlenme süreleri, beslenme, özlük hakları, kişisel koruyucular gibi etmenler iş kazası oluşum sürecinin belirleyicileridir. Sayılan bu etmenlerin, insan sağlığı ile uyumlu hale getirilmesi, iş kazalarının önlenmesi bakımından temel yaklaşım olmalıdır. İş kazası olgusu toplumsal bir olgudur. Kazaların bizzat mağdurları, onların örgütü olan sendikalar ve onları temsilen politika yaptığı iddiasına sahip olan yapıların, bu anlayışla mücadele etmeleri gerekmektedir. $\mathrm{Bu}$ mücadelenin etkinliğini sağlayacak en önemli faktörlerden birisi de elbette konuya ilişkin bilgi, deneyim ve bunların paylaşımı olacaktır. Büyük ölçekli pek çok iş yerinde iş kazalarının önlenmesine yönelik programlar geliştirilmekte ve uygulanmaktadır. Ulusal düzeyde iş kazalarına bağlı morbidite, mortalite ve ekonomik kayıların azaltılmasında bu tür programların hızla tüm iş yerlerinde yaygınlaştırılması gerekmektedir.

Etik Kurul Kararı: Dicle Üniversitesi etik kurulu tarafindan 26.02.2016 tarihinde 111 sayı numarası ile etik onay verildi.

Çıkar Çatışması Beyanı: Yazarlar çıkar çatışması olmadığını bildirmişlerdir.

Finansal Destek: Bu çalışma her hangi bir fon tarafından desteklenmemiştir.

Declaration of Conflicting Interests: The authors declare that they have no conflict of interest.

Financial Disclosure: No financial support was received.

\section{KAYNAKLAR}

1. Erkan N. Ergonomi. 6.Baskl, Ankara: Milli Prodüktivite Merkezi Yayını, Yayın No: 373 Mert Matbaası, 2001.
2. Akbulut T. İşçi Sağlığına Giriş, (İşyeri Hekimliği Ders Notları İcinde). 6. Baskı, Ankara: Türk Tabipleri Birliği Yayını, No:011/01, 45, 2001.

3. Akbulut T. İș Sağlığı Prensip Ve Uygulamaları. 1. Baskı, İstanbul: Sistem Yayıncılık, 1994.

4. Yardım N, Çipil Z, Vardar C et al. Türkiye İş Kazaları Ve Meslek Hastalıkları: 2000-2005 Yılları Olum Hızları. Dicle Tıp Dergisi 2007; 34: 264-71.

5. Aybek A, Güvercin O, Hurşitoğlu C. Teknik Personelin İş Kazalarının Nedenleri Ve Önlenmesine Yönelik Görüşlerinin Belirlenmesi Üzerine Bir Araştırma. Ksu Fen Ve Mühendislik Dergisi 2003; 6: 91-100.

6. İlhan M.N, Kurtcebe Z.O, Durukan E et al. Temizlik İşçilerinin Sosyo- Demografik Özellikleri Ve Çalışma Koşulları İle İş̧ Kazaları Ve Meslek Hastalıkları Sıklığl. Fırat Üniversitesi Sağlık Bilimleri Dergisi 2006; 20: 433-9.

7. Perry $\mathrm{Mj}$, Sun $\mathrm{Bx}$, Zhang $\mathrm{Hx}$ et al. Emergency Department Surveillance Of Occupational İnjuries İn Shanghai's Putuo District, People's Republic Of China. Ann Epidemiol 2005; 15: 351-7.

8. ILO (International Labour Office), http://laborsta.ilo.org.09.07.2020

9.

http://www.sgk.gov.tr/wps/portal/sgk/tr/kurums al/istatistik/sgk_istatistik_yilliklari 09.07.2020

10. Karakurt Ü, Satar S, Acıkalın A et al. Acil Tıp Kliniğine Başvuran İş Kazalarının Analizi. DOI:10.5152/jaem.2012.031 Corpus ID: 75622744.

11. Türkmen N, Şenel B, Şam B et al. İstanbul'da İş Kazasina Bağlı Ölümler. Journal of Forensic Medicine Adli Tıp Dergisi 2005; 19: 29-36.

12. Avcıbaşı İ M. (2016) Edirne Merkezdeki Bir Giyim Fabrikasında Çalışan İşçilerin Çalışma Duruşlarının İş Kazaları ile İlişkisi. Yüksek Lisans Tezi, Ulusal Tez Merkezi 424676. 2016.

13. Bilgen M. Ankara'da Elektrik Dağıtım İşlerinde Çalışan İşçilerde İş Kazaları Ve Meslek Hastalıkları Görülme Sıklığı İle İlişkili Etmenler. T.C. Çalışma ve Sosyal Güvenlik Bakanlığı Çalışma ve Sosyal Güvenlik Eğitim ve Araştırma Merkezi Yayınları Yayın No: 37 Ankara-2013 
14. Lordoğlu K. Bir Kamu İşletmesindeki İş Kazaları Ve Nedenleri Üzerine Bazı Notlar. Ocak-Şubat 1985 Merinos (Bursa) Sümerbank işletmesi. Sosyal Siyaset Konferansları Dergisi Arşiv Cilt 0, Sayı 3536/1986.

15. Yüksel İ. Kurt M. Dizdar E.N. Atatürk Barajı Ve Hidroelektrik Santralinin Yapımında Meydana Gelen İş Kazalarının Analizi. Teknoloji, Yıl 5 (2002), Sayı 34, 105-11.

16. Ayoğlu F.N. Kıran S. Şahin Z et al. Türkiye Taşkömürü Kurumu Kozlu Müessesesi'nde 2004 Yılında Gerçekleşen İş̧ Kazalarının Değerlendirilmesi. Türk tabipleri birliği mesleki sağlık ve güvenlik dergisi Ekim-Kasım-Aralık 2006.

17. Dağlı B, Serinken M. Acil Servise Başvuran İş Kazalarına Bağlı Yaralanmalar. The Journal of Academic Emergency Medicine. JAEM 2012; 11: 167-70

18. Çopur Z, Varlı B, Avşar M et al. Ege Üniversitesi Hastanesinde Çalışan Ev İdaresi Personelinin İş Kazası Geçirme Durumlarının İncelenmesi. Sağlık İdaresi Dergisi, Cilt:9, Sayı:2 (2006).
19. Duman E. Hamzaoğlu O. İstanbul'da Bir Şantiyede Çalışanların İş Kazalarının İzlemi. Türk Tabipleri Birliği Mesleki Sağlık Ve Güvenlik Dergisi. Nisan-Mayıs-Haziran 2011.

20. Kalemoğlu M, Keskin O, Yıldırım İ et al. Acil Servise Başvuran Travmatik İş Kazalarının İncelenmesi. Nobel Medicus 2006 (Online Dergi). www.nobelmedicus.com/ Contents/200621/2123.Htm. Erişim 10.06.2015.

21. Kıran S, Konuk N, Atık L et al. Kazasına Bağlı Yaralanmalarda Alkol Kullanımı. Bağımlılık Dergisi 2006; 7: 123-8.

22. Satar S, Kekec Z, Sebe A et al. Çukurova Üniversitesi Tıp Fakultesi Acil Tıp Anabilim Dalına Başvuran İş Kazası Olgularının Analizi. Çukurova Üniversitesi Tıp Fakultesi Dergisi 2004; 29: 118-27.

23. Sayhan MB, Sayhan ES, Yemenici $S$ et al. Occupational injuries admitted to the emergency department. J Pak Med Assoc. 2013; 63: 179-84.

24. Salt O, Sayhan MB, Küçükyağcı N. Occupational Injuries Among The Elderly Admitted to The Emergency Department. Turkish Journal of Geriatrics 2019;22: 83-90. 